\title{
Awareness women of childbearing age on early detection cervical cancer: a scoping review
}

\author{
Siti Rukmana ${ }^{*}$, Dewi Rokhanawati ${ }^{2}$, Nurul Kurniati ${ }^{3}$ \\ ${ }^{1}$ Student of Midwifery Magister Program, Universitas 'Aisyiyah Yogyakarta, Indonesia, Jl. Siliwangi No.63 Mlangi, \\ Nogotirto, Sleman, Yogyakarta (55592), Indonesia \\ ${ }^{2,3}$ Lecture Faculty of Health Science, Universitas 'Aisyiyah Yogyakarta, Indonesia, Jl. Siliwangi No.63 Mlangi, \\ Nogotirto, Sleman, Yogyakarta (55592), Indonesia \\ ${ }^{1}$ sitirukmana0794@gmail.com*,2dewirokhanawati@gmail.com, 33nurul.kurniati@unisayogya.ac.id \\ *corresponding author
}

Submission date: 23 Maret 2021, Receipt date: 4 Mei 2021, Publication date: 1 November 2021

\begin{abstract}
Cervical cancer is caused by HPV acquired by sexual intercourse. Women know that screening is done to detect cervical cancer early. The purpose of this review is to determine the awareness of early detection of cervical cancer in women of childbearing age. Scoping Review by Arksey and O'Malley. Date based are Wiley, Pubmed, Proquest and EBSCO. 9 articles were reviewed by JBI. The results revealed the factors that influence women for early detection types of cervical cancer form of knowledges and education, good knowledge can generate women's awareness of early detection, health promotion and socialization from healthcare proffessionals is very influential.
\end{abstract}

Keyword: awareness; cervical cancer early detection; screening; women of childbearing

\section{INTRODUCTION}

Cervical cancer caused by sexually acquired HPV infection killed more than 270,000 women each year, $85 \%$ of which are in developing countries. Woman's cervical cancer mortality has been resolved in developed countries, but cervical cancer is leading cause of deaath among women mortality in developing countries (UNFPA, 2015). The global cancer problem is entering a critical period, where the incidence of cancer is increasing each year. So far, cervical cancer has been the leading the cause of death for women in developing countries (WHO, 2016).

Based on GLOBOCAN 2012, cervical cancer ranks 7th in the word in incidence (6th the least in developed countries) and 8th in cause of death (accounting for $3.2 \%$ of mortality). Cervical cancer is in the highest position at developing country, and is ranked $10^{\text {th }}$ or 5th in developed country (Andrijono, 2017). The number of cancer patients projected to increase year by year, estimated to be 12 million people in 2030. It's estimated that 6.25 million new cancer patients ara added each year, making up more than 30 part of the 100,000 population. Cervical cancer is the fourth most common cancer in women and is most common cancer with overall. Approximately 528,000 new sufferers of cervical cancer have emerged, with up to 266,000 death from cervical cancer, accounting for an estimated $7.5 \%$ of cancer deaths worldwide (WHO, 2018).

Low knowledges of cervical cancer, misdiagnosis of cancer, and a negative attitude towards surgery are factors related for screening of cervical cancer. Low knowledge, lack of awareness about screening method used can be very influential 
conducting cervical cancer screening (Endalew et al., 2020). Beliefs, culture, and negative perceptions of cancer are also a major cause of low cervical cancer screening rates (Fentie et al, 2020)

Less awareness of HPV, most women recognize cervical cancer as a disease, and one third of women know people with cervical cancer. Once basic health information is available, woman understand the benefits of screening to preventing development of cancer and do more than screening if given the opportunity to be done (McCarthy et al, 2017). Barriers to accessing and ingesting information about HPV, such as lack of information about HPV, experience, perceptions of women about behavior, attitudes health workers, and the limited information available on the internet (O'Connor et al, 2015). Vulnerabilities are often associated with poor health literacy and poor compliance with health promotion programs. Factors particulary related to famale vulnerability are destitution, less ow educational attainment, unemployment and immigrant/refugee status. (Riza et al., 2020). Several factors are associated with a high-risk of HPV infections and a high prevalence rate of cervical cancer. Knowledges and attitudes to on these issues is critical to increasing the use of primary and secondary preventive interventions (Bhatt \& Bathija, 2018). Efforts to identify early symptoms of cervical cancer can be made throungh comprehensive cervical cancer screening and healthy socialization now recognized as a way to prevent cervical cancer in women (Cunningham et al., 2015). The role of health workers and healthcare providers can be supporting enhancement women's factor in screening for cervical cancer (Al-Amro et al,2020)

The development countries, effective screening programs, especially Pas smear, have overcome casses of cervical cancer because the next stage of cervical cancer could be prevented by screening and therapy, but many screening are done. Tasting in developing countries is still inadequate and inaccessible to most people such as in Cambodia which is a developing country (Touch \& Oh, 2018). Women believe that Pap smear are useful for detecting cervical cancer and they are willing to undergo a Pap smear test if allowed to do (Heena et al., 2019).

Human Papilloma Virus is the leading caused of cervical cancer, which transmitted through sexual contact. Multiple sexual partners, childhood sexual activity, many children, early marriage and childbirth, lack of cleanliness hygiene of female organs, low social economic status, use of hormonal contraceptives for more than 5 years sexually transmitted diseases and smoking is one of the risk factors (Kasa et al, 2018). Women suffering from cervical cancer experience physical, financial, psychological, and charitable problems st they daily lives that affects their quality of life, decreasing the less of knowledges of cervical cancer has been shown to pose a threat to prevent and treat (Binka et al, 2017). HPV vaccination is the solution to eradicate cervical cancer in developing and developed countries (Yuanyue et al., 2018)

In this case, the author would like to know the awareness of women of childbearing at Asia regarding teh screening of cervical cancer, especially for perception of cervical cancer coused by the ignorance and lack of human resources of woman in developing countries. The author focuses on Asian women because of the similarities of the social system, cultures, geographic locations and races. According to the author's view that Asia is a country with a distinctive biological, social, psychological, and cultural 
profiles, based on their beliefs about the value of reproduction, the language used to describe and discuss cervical cancer.

\section{RESEARCH METHODS}

Scoping Review uses a methodology for clustering reviews performed by Arksey and O'Malley and further developed by Levac et al. There are four reasons for the scoping reviews: (1) examining the scope and nature of the research activities, (2) determining the value full systematic review. (3) collection and disseminate of research results, and (4) identifying of research gaps in the existing literature (Arksey \& O'Malley, 2005) (Levac et al., 2010). The phases perforemed in this review include: (1) identifying scoping review questions, (2) identify relelated studies, (3) selecting studies, (4) mapping thems, (5) compilation, summarize, and reporting results.

\section{Identify Research Questions}

PEOs (Population, Exposure, Outcome, Study) can identify the key focus questions, develop appropriate search terms to explain the problem and determine inclusion and exclusion criteria (Bettany, 2012).

Table 1. Framework Research Question PEOS

\begin{tabular}{|c|c|c|c|}
\hline Element & Inclusion criteria & Exclusion criteria & Rationale \\
\hline Population & $\begin{array}{l}\text { Women of childbearing } \\
\text { Age }\end{array}$ & $\begin{array}{l}\text { Women aged }<15 \\
\text { years and }>50 \text { years }\end{array}$ & $\begin{array}{l}\text { Women aged } 15- \\
49 \text { years }\end{array}$ \\
\hline Exposure/Event & $\begin{array}{l}\text { Detection Early cervical } \\
\text { cancer }\end{array}$ & & \\
\hline Outcome & $\begin{array}{l}\text { Awareness women of } \\
\text { childbearing age }\end{array}$ & & $\begin{array}{ll}\text { Awareness } & \\
\text { women } & \text { of } \\
\text { childbearing } & \text { to } \\
\text { early detection } & \text { of } \\
\text { cervical cancer } & \end{array}$ \\
\hline Study Design & $\begin{array}{l}\text { Qualitative study } \\
\text { Quantitative Study }\end{array}$ & & \\
\hline
\end{tabular}

Based on the PEOS framework above, the question scoping review is how the awareness women of childbearing at early detection of cervical cancer?

\section{Identifying Relevant Studies}

a. Inclusions and Exception Criteria

Scoping review researchers will identify relevant articles that used inclusion and exclusion criteria. Inclusion criteria used by researchers include articles published in 2011-2020, articles published in Indonesian and English, original articles, research conducted in developing countries and documents/reports/ draft policies/guidelines from $\mathrm{WHO} /$ specific formal organization. Under the inclusion criteria, the reason for choosing articles in the last 10 years is because it includes major policy changes such as SDG's, scientific is dynamic and up to date and researchers want to choose the latest evidence, articles published in English or Indonesian because of the language skills of bilingual researchers and original articles because researchers focus on articles that have not been reviewed. The exclusion criteria for this study were opinion articles, systematic reviews, letters and book reviews, articles that did not-full-text and articles titled English translated but into other languages. 


\section{b. Data-Based Used}

Scoping Review, the researcher identified relevant studies where the data based used in the search for this article included Pubmed, Ebsco, Proquest, Wiley, and Grey Literature by using keywords that the authors identified a related topic of scoping in the search process.

\section{Selection Relevant Studies}

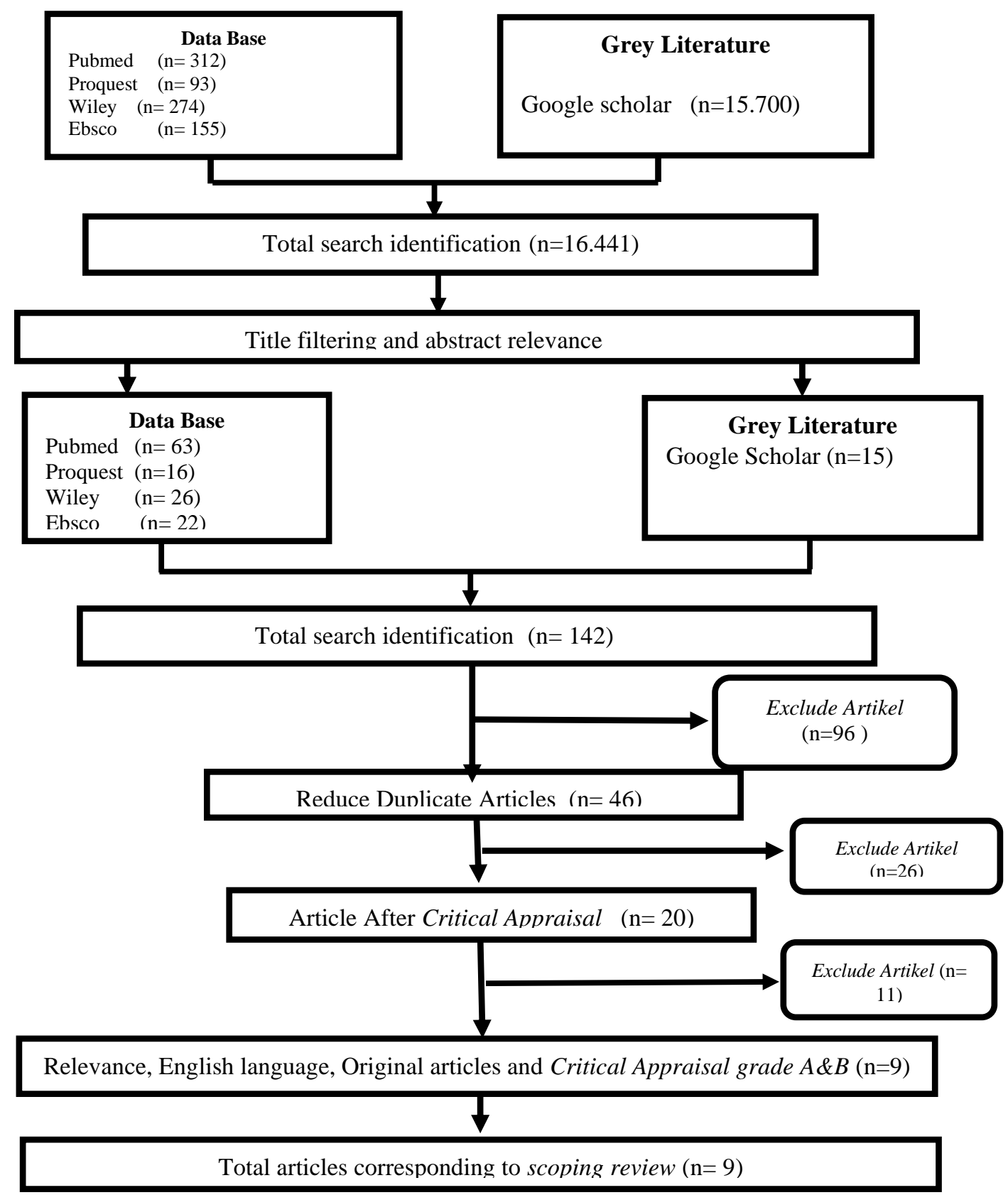

Figure 1. Prisma Flow Chart 


\section{Charting Data}

Table 2. Charting Data

Title /

\begin{tabular}{|c|c|c|c|c|c|c|}
\hline No & $\begin{array}{l}\text { Author / } \\
\text { Year / } \\
\text { Value }\end{array}$ & Objective & $\begin{array}{l}\text { Type of } \\
\text { research }\end{array}$ & $\begin{array}{c}\text { Data } \\
\text { collection }\end{array}$ & $\begin{array}{l}\text { Participants / } \\
\text { Sample size }\end{array}$ & Result \\
\hline 1. & $\begin{array}{l}\text { Awareness of } \\
\text { Cervical } \\
\text { Cancer } \\
\text { Causes and } \\
\text { Predetermina } \\
\text { nts of } \\
\text { Likelihood to } \\
\text { Screen } \\
\text { Among } \\
\text { Women in } \\
\text { Haiti } \\
\text { (McCarthy et } \\
\text { al, 2017) }\end{array}$ & $\begin{array}{l}\text { To find out } \\
\text { famale } \\
\text { knowledge } \\
\text { about } \\
\text { causes of } \\
\text { cervical } \\
\text { cancer, } \\
\text { socioldemo } \\
\text { graphy and } \\
\text { the role of } \\
\text { workers } \\
\text { health for } \\
\text { cervical } \\
\text { cancer } \\
\text { screening. }\end{array}$ & $\begin{array}{l}\text { Cross } \\
\text { sectional } \\
\text { Study }\end{array}$ & $\begin{array}{l}\text { Questionnair } \\
\text { es }\end{array}$ & $\begin{array}{l}410 \text { women } \\
\text { who attended } \\
\text { the Port-au- } \\
\text { Prince clinics } \\
\text { in Haiti }\end{array}$ & $\begin{array}{l}29 \% \text { of participant } \\
\text { who have heard } \\
\text { about Human } \\
\text { papilloma } \\
\text { virus (HPV), } 98 \% \\
\text { are awareness of } \\
\text { cervical cancer, 12\% } \\
\text { believe infections } \\
\text { sexual transmitted } \\
\text { lead to cervical } \\
\text { cancer, and only } 4 \% \\
\text { identify HPV a } \\
\text { caused of cervical } \\
\text { cancer. Almost all } \\
\text { women (97\%) are } \\
\text { want to do early } \\
\text { detection. The } \\
\text { woman of Haitian } \\
\text { have limited limited } \\
\text { consciousness about } \\
\text { HPV and did'nt } \\
\text { know the factors } \\
\text { caused of cervical } \\
\text { cancer. }\end{array}$ \\
\hline 2 & $\begin{array}{ll}\text { Knowle } & \text { To } \\
\text { dge and } & \text { cer } \\
\text { Awaren } & \text { awa } \\
\text { ess of } & \text { low } \\
\text { Cervical } & \text { serv } \\
\text { Cancer } & \text { beh } \\
\text { among } & \\
\text { HIV- } & \\
\text { Infected } & \\
\text { Women } & \\
\text { in } \\
\text { Ethiopia } \\
\text { (Shifera } \\
\text { w et al, } \\
\text { 2016) }\end{array}$ & $\begin{array}{l}\text { letermine the } \\
\text { ical cancer } \\
\text { eness with } \\
\text { health } \\
\text { ce seeking } \\
\text { vior. }\end{array}$ & $\begin{array}{l}\text { Cross } \\
\text { sectional } \\
\text { study }\end{array}$ & $\begin{array}{l}\text { Questionnair } \\
\text { es and } \\
\text { interviews }\end{array}$ & $\begin{array}{l}\text { Women } \\
\text { suffering from } \\
\text { HIV between } \\
21 \text { and } 49 \text { years } \\
\text { old }\end{array}$ & $\begin{array}{l}432 \text { woman infected } \\
\text { HIV. } 71 \% \text { the } \\
\text { participant have } \\
\text { heard of cervical } \\
\text { cancer, } 49 \% \text { do not } \\
\text { know the caused } \\
\text { temporary } 74 \% \\
\text { capable of knowing } \\
\text { one of several risk } \\
\text { factors for cervical } \\
\text { cancer. 33\% women } \\
\text { seeking medication } \\
\text { and 33\% choose an } \\
\text { option for servical } \\
\text { cancer treatment. } \\
\text { This research } \\
\text { suggest, if } \\
\text { knowledge about } \\
\text { cervircal cancer still } \\
\text { less, especially for } \\
\text { search cervical } \\
\text { cancer therapy. }\end{array}$ \\
\hline 3 & $\begin{array}{l}\text { Awaren } \\
\text { ess of } \\
\text { cervical } \\
\text { cancer }\end{array}$ & $\begin{array}{l}\text { wing } \\
\text { eness of } \\
\text { ical cancer } \\
\text { ng Moroccan }\end{array}$ & $\begin{array}{l}\text { Cross- } \\
\text { sectional } \\
\text { study }\end{array}$ & $\begin{array}{l}\text { Questionnair } \\
\mathrm{e} \quad \text { and } \\
\text { interviews }\end{array}$ & $\begin{array}{l}123 \text { women } \\
\text { positive HIV- } \\
\text { aged } 19 \text { years } \\
\text { and older }\end{array}$ & $\begin{array}{l}\text { The ware a total of } \\
115 \text { famale } \\
\text { participating. } \\
\text { Average age } 34.9\end{array}$ \\
\hline
\end{tabular}




\begin{tabular}{|c|c|c|c|c|c|c|}
\hline & $\begin{array}{l}\text { among } \\
\text { women } \\
\text { attendin } \\
\mathrm{g} \text { an } \\
\text { HIV } \\
\text { treatme } \\
\text { nt } \\
\text { center: a } \\
\text { cross- } \\
\text { sectiona } \\
\text { l study } \\
\text { from } \\
\text { Morocc } \\
\text { o } \\
\text { (Belglai } \\
\text { aa et al, } \\
\text { 2018) }\end{array}$ & $\begin{array}{l}\text { women attending } \\
\text { an HIV clinic in } \\
\text { Laayoune, } \\
\text { Morocco. }\end{array}$ & & & & $\begin{array}{l}\text { years old. } 20 \% \\
\text { woman have heard } \\
\text { about cervical cancer } \\
\text { and have been } \\
\text { screened, mostly } \\
(17.4 \%) \text { heard } \\
\text { information form } \\
\text { mass media. } 79.1 \% \\
\text { of respondents were } \\
\text { unaware of risk } \\
\text { factors, and } 80,8 \% \\
\text { were awere the signs } \\
\text { and symptoms of } \\
\text { cervical cancer. } \\
\text { Only } 13 \% \text { had a Pap } \\
\text { smear. Main reasons } \\
\text { not do paps smear is } \\
\text { because there were } \\
\text { no signs and } \\
\text { symptoms (47\%) }\end{array}$ \\
\hline 4 & $\begin{array}{l}\text { Underst } \\
\text { anding } \\
\text { and } \\
\text { Respons } \\
\text { iveness } \\
\text { Level } \\
\text { about } \\
\text { Cervical } \\
\text { Cancer } \\
\text { and its } \\
\text { Avoida } \\
\text { nce } \\
\text { among } \\
\text { Young } \\
\text { Women } \\
\text { of } \\
\text { Pakistan } \\
\text { (Khan et } \\
\text { al, } \\
\text { 2014) }\end{array}$ & $\begin{array}{l}\text { To know } \\
\text { awareness of } \\
\text { young women in } \\
\text { Pakistan about } \\
\text { cervical cancer } \\
\text { and to educate } \\
\text { they about } \\
\text { cervical cancer }\end{array}$ & $\begin{array}{l}\text { Cross } \\
\text { sectional } \\
\text { study }\end{array}$ & $\begin{array}{l}\text { Questionnair } \\
\text { e }\end{array}$ & $\begin{array}{l}3 \text { educational } \\
\text { institutions } \\
873 \text { women } \\
\text { (including } \\
\text { medical, non- } \\
\text { medical and } \\
\text { uneducated } \\
\text { communities) }\end{array}$ & $\begin{array}{l}70.1 \% \text { really } \\
\text { properly aware of } \\
\text { cervical cancer. } \\
8.5 \% \text { of entire } \\
\text { populations know } \\
\text { accurated a about of } \\
\text { cervical cancer, } 7 \% \\
\text { respondents stated } \\
\text { human papilloma } \\
\text { virus as causative } \\
\text { agent. 5.2\% of } \\
\text { respondents had Pap } \\
\text { smears to determine } \\
\text { the diagnosis. only } \\
4.3 \% \text { of individuals } \\
\text { are vaccinated and } \\
\text { the largely come } \\
\text { from health } \\
\text { professionals, } \\
\text { student, woman } \\
\text { worked, housewives } \\
\text { and educated famela take } \\
\text { an active part of } \\
\text { survey. }\end{array}$ \\
\hline
\end{tabular}




\begin{tabular}{|c|c|c|c|c|c|c|}
\hline 5 & $\begin{array}{l}\text { Are } \\
\text { Primary } \\
\text { Health } \\
\text { Care } \\
\text { Worker } \\
\text { s Aware } \\
\text { of } \\
\text { Cervical } \\
\text { Cancer } \\
\text { Risk? } \\
\text { (Can et } \\
\text { al, } \\
\text { 2014) }\end{array}$ & $\begin{array}{l}\text { To check } \\
\text { awareness of } \\
\text { woman health } \\
\text { workers (doctors, } \\
\text { nurses, } \\
\text { midwives) } \\
\text { working in the } \\
\text { healthcare setting } \\
\text { about cervical } \\
\text { cancer and risk } \\
\text { factors }\end{array}$ & $\begin{array}{l}\text { Cross- } \\
\text { sectional } \\
\text { study }\end{array}$ & $\begin{array}{l}\text { Interview } \\
\text { and } \\
\text { questionnair } \\
\text { e }\end{array}$ & $\begin{array}{l}\text { A total of } 327 \\
\text { ladies health } \\
\text { workers }\end{array}$ & 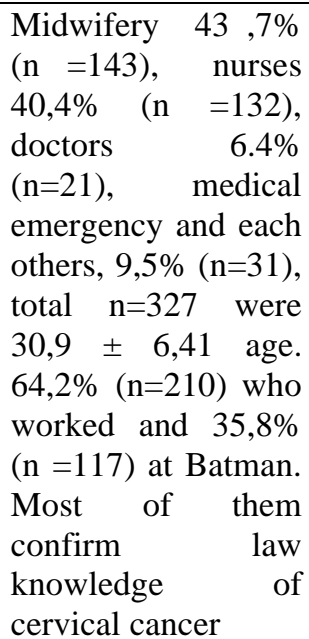 \\
\hline 6 & $\begin{array}{l}\text { Percepti } \\
\text { ons and } \\
\text { concern } \\
\mathrm{s} \text { of } \\
\text { women } \\
\text { undergo } \\
\text { ing Pap } \\
\text { smear } \\
\text { examina } \\
\text { tion in a } \\
\text { tertiary } \\
\text { care } \\
\text { hospital } \\
\text { of India } \\
\text { (Tiwari, } \\
\text { et al } \\
\text { 2011) }\end{array}$ & $\begin{array}{l}\text { To know } \\
\text { awareness about } \\
\text { cervical cancer } \\
\text { risk factors, } \\
\text { health seeking } \\
\text { and } \\
\text { practices among } \\
\text { female and to } \\
\text { find out the stress } \\
\text { experienced } \\
\text { women } \\
\text { before Pap smear }\end{array}$ & $\begin{array}{l}\text { Cross } \\
\text { Sectional } \\
\text { Study }\end{array}$ & $\begin{array}{l}\text { Questionnair } \\
\mathrm{e} \quad \text { and } \\
\text { interviewed }\end{array}$ & $\begin{array}{l}250 \text { patients } \\
\text { from hospitals } \\
\text { in New Delhi } \\
\text { gynecological } \\
\text { wards OPD }\end{array}$ & $\begin{array}{l}57 \% \text { do not consult a } \\
\text { doctor when first } \\
\text { experiencing } \\
\text { symptoms. } 61 \% \text { do } \\
\text { not know cervical } \\
\text { cancer and pap } \\
\text { smears. Older, } \\
\text { muslim and } \\
\text { educated female } \\
\text { have abnormal Pap } \\
\text { smear results higher. } \\
\text { Women who } \\
\text { experience stress in } \\
\text { them life have } \\
\text { abnormal results } \\
\text { compared to women } \\
\text { who live freely. } \\
\text { Hygienic practices } \\
\text { were lower in urban } \\
\text { woman are related } \\
\text { the results inspection } \\
\text { abnormal. }\end{array}$ \\
\hline 7 & $\begin{array}{l}\text { Knowle } \\
\text { dge and } \\
\text { Awaren } \\
\text { ess of } \\
\text { Cervical } \\
\text { Cancer } \\
\text { Screeni } \\
\text { ng } \\
\text { Among } \\
\text { Women } \\
\text { of } \\
\text { Reprod } \\
\text { uctive } \\
\text { Age in } \\
\text { Ikere } \\
\text { Ekiti } \\
\text { Local } \\
\text { Govern } \\
\text { ment } \\
\text { Area, }\end{array}$ & $\begin{array}{l}\text { To find out how } \\
\text { often } \\
\text { woman of } \\
\text { childbearing age } \\
\text { cary out cervical } \\
\text { cancer screening }\end{array}$ & $\begin{array}{l}\text { Cross } \\
\text { sectional } \\
\text { Study }\end{array}$ & $\begin{array}{l}\text { Questionnair } \\
\text { es and } \\
\text { interviews }\end{array}$ & $\begin{array}{l}\text { Women of } \\
\text { reproductive } \\
\text { age with } \\
\text { susceptible age } \\
\text { of 18-50 years. }\end{array}$ & $\begin{array}{l}\text { Women } \\
\text { childbearing age in } \\
\text { Ikere Nigeria have } \\
\text { low knowledge } \\
\text { about cervical cancer } \\
\text { and ways for } \\
\text { prevention. The } \\
\text { survey found that } \\
\text { respondent's } \\
\text { knowladge of } \\
\text { cervical did not } \\
\text { significantly affect } \\
\text { the educational } \\
\text { equality of their } \\
\text { financial and family } \\
\text { status }\end{array}$ \\
\hline
\end{tabular}




\begin{tabular}{|c|c|c|c|c|c|c|}
\hline & $\begin{array}{l}\text { Ekiti } \\
\text { State, } \\
\text { Nigeria } \\
\text { (Obalas } \\
\text { e et al, } \\
\text { 2017) }\end{array}$ & & & & & \\
\hline 8 & $\begin{array}{l}\text { Seropre } \\
\text { valence } \\
\text { and } \\
\text { awarene } \\
\text { ssof } \\
\text { human } \\
\text { papillo } \\
\text { ma virus } \\
\text { infectio } \\
\text { n and } \\
\text { cervical } \\
\text { cancer } \\
\text { screenin } \\
\text { g results } \\
\text { among } \\
\text { reprodu } \\
\text { ctive- } \\
\text { aged } \\
\text { Georgia } \\
\mathrm{n} \\
\text { women } \\
\text { (Butsas } \\
\text { hvili et } \\
\text { al, } \\
\text { 2015) }\end{array}$ & $\begin{array}{l}\text { To know } \\
\text { awarnnes about } \\
\text { the HPV, cervical } \\
\text { cancer screening, } \\
\text { HPV vaccine and } \\
\text { HPV infection } \\
\text { seroprevalence } \\
\text { among women of } \\
\text { reproductive age } \\
\text { Georgia }\end{array}$ & $\begin{array}{l}\text { Cross- } \\
\text { sectional } \\
\text { study }\end{array}$ & $\begin{array}{l}\text { Questionnair } \\
\mathrm{e} \quad \text { and } \\
\text { interviews }\end{array}$ & $\begin{array}{l}500 \\
\text { participants in } \\
\text { Georgia with a } \\
\text { vulnerable age } \\
18-48 \text { year }\end{array}$ & $\begin{array}{l}52,0 \% \text { knew about } \\
\text { HPV and } 36,4 \% \text { said } \\
\text { HPV was by main of } \\
\text { caused. Them aware } \\
\text { of HPV, } 78 \% \text { say } \\
\text { they have detected } \\
\text { cervical cancer at } \\
\text { least once early. } \\
50,8 \% \text { respondents } \\
\text { did not know HPV } \\
\text { vaccine. Famales } \\
\text { (n=317) who agreed } \\
\text { to test for anti-HPV } \\
\text { antibodies, } 21,1 \% \\
\text { were cancer } \\
\text { positive. }\end{array}$ \\
\hline 9 & $\begin{array}{l}\text { Health } \\
\text { seeking } \\
\text { behavio } \\
\mathrm{r} \text { and its } \\
\text { determi } \\
\text { nants } \\
\text { for } \\
\text { cervical } \\
\text { cancer } \\
\text { among } \\
\text { women } \\
\text { of } \\
\text { childbea } \\
\text { ring age } \\
\text { in } \\
\text { Hossana } \\
\text { Town, } \\
\text { Hadiya } \\
\text { zone, } \\
\text { Souther } \\
\text { n } \\
\text { Ethiopia } \\
\text { : } \\
\text { commu } \\
\text { nity } \\
\text { based } \\
\text { cross } \\
\end{array}$ & $\begin{array}{l}\text { To determine } \\
\text { treatment seeking } \\
\text { behavior and } \\
\text { determinants the } \\
\text { occurrence of } \\
\text { cervical cancer in } \\
\text { the city of } \\
\text { Hossana }\end{array}$ & $\begin{array}{l}\text { Cross- } \\
\text { sectional } \\
\text { Study of } \\
\text { community- } \\
\text { based. }\end{array}$ & $\begin{array}{l}\text { Questionnair } \\
\mathrm{e}\end{array}$ & $\begin{array}{l}500 \text { women of } \\
\text { childbearing } \\
\text { age with } \\
\text { susceptible age } \\
\text { 15-49 years }\end{array}$ & 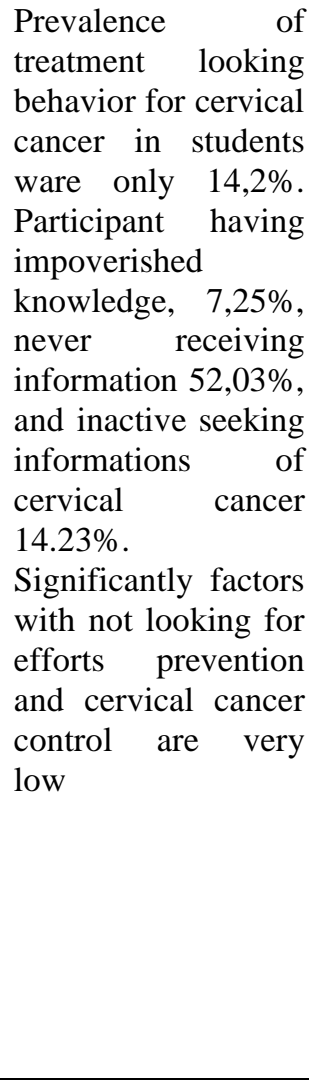 \\
\hline
\end{tabular}


sectiona

1 study

(Habtu

et $a l$,

2018)

\section{Scoping Theme Data Collection and Mapping}

The results of review 9 articles from developing countries. Research design is $a$ cross-sectional quantitative study with data collection techniques using questionnaires and interviews. Based on the results of critical appraisal using the Joanna Briggs Institute Tools, it was found that 5 articles were grade (A) with very good quality and 4 articles with good quality is grade (B).

Table 3. Mapping dan Sub Theme

\begin{tabular}{|c|c|}
\hline THEME & SUB THEME \\
\hline Influencing factors & $\begin{array}{ll}\text { 1. } & \text { Knowladge }^{1,2,3,4,5,8,9} \\
\text { 2. } & \text { Education } 2,3,4,6,7,8,9 \\
\text { 3. } & \text { Informations }{ }^{1,2,3,4,6 ; 7,8,9} \\
\text { 4. } & \text { Economic status } \\
\text { 5. } & \text { Experience } \\
1,3,7,8\end{array}$ \\
\hline Decision making & $\begin{array}{l}\text { 1. Do it }{ }^{1,8} \\
\text { 2. Not do it } 2,3,9\end{array}$ \\
\hline Barries & Shy and worried $3,4,6,9$ \\
\hline
\end{tabular}

\section{RESULTS AND DISCUSSION}

\section{Influencing Factors}

One of predisposing factors for women to screening cervical cancer early is knowledge where good knowledge can raise woman's awareness to screening of cervical cancer. Likewise, if less knowledge will affect women should not be screened for cervical cancer, it may be due to less information. This is due to health care worker's promotion and lack of public support. A high level of learning and consciousness about cervical cancer plays a very important for improve health services. A study conducted in Ethiopia shows that awareness is influenced by knowledge, where the results show that $71 \%$ of woman has heard about cervical cancer and some have very low knowledge (Shiferaw et al, 2016). Overall, almost all women (98\%) knew about cervical cancer, although only $29 \%$ of women said they had ever heard of HPV. 51\% of women who have heard of cervical cancer said it was caused by a vaginal infection or a gynecological problem (McCarthy et al, 2017).

Pakistani women are fairly well aware of the risks of cervical cancer, but few sources of information about cervical cancer (Khan et al, 2014). If a woman has clear information about the risk factors and causes of cervical cancer, it's very helpful for her to take precautions (Shiferaw et al, 2016). Various sources of information that are easily accessible to women of childbearing potential will improve their knowledge of cervical cancer and screening be better. The media role 
in the transfer of knowledge is more effectively used to spread information on cervical cancer.

Low levels of education give women poor knowladge, and education people broader knowledge and developed mindset, increasing their awareness of positive behavior, including health, increase. Education can promote woman's empowerment, increase their knowledge of the importance of early detection of cervical cancer and to link cervical cancer awareness with social status, women from high social classes have six confirmed cases of cervical cancer compared to women from low social classes, This may be because education women may have more than awareness and information uneducated (Belglaiaa et al, 2018). Judging by the educational status of Indian women, if an educated woamn is observed to have a large number of abnormal pap smear, this may be due to more active healthseeking behaviors. Lack of training in cervical cancer screening but lack of health education makes it difficult for health care providers to implement screening programs such as annual Pap smears in accordance with international guidelines (Tiwari et al, 2011)

Cervical cancer is also age-related. Women aged 35-39 are five times more likely to be screened cervical cancer than women aged 25-29, this may be because older women can visit a medical facility for a variety of gynecological problems and then quickly get immediate cervical cancer screening and famale who have tested for HIV are screened for cervical cancer more than they who have not been tested for HIV, the chances are almost tripled (Gemeda et al., 2020)

Healthcare professionals play an important role as health educators and promoters. Pap smear screening were higher for health care workers who were informed about pap smear, recewived regulary gynecology treatment, and were informed about cervical cancer, the risk, HPV and other injections (Can et al., 2014). Most Georgian interviewed women too pointed out televisions and print media are good methods of communications. The results view importance of developing and launch more comprehensive public outreach using media to increased knowledge and awareness about HPV (Butsashvili et al, 2015).

\section{Decision Making}

The decision is the best conclusion that can be drawn from assessing various information related for early detection of cervical cancer. Decision making is very important in setting goals through the implementation of actions. Despite low levels awareness of HPV, most all women recognize cervical cancer as a fetal diseases, and one third of women they have it. After receiving basic health information, women understand the benefits of early detection to the prevent of cervical cancer development after receiving the basics of health information and they are more than willing to undertake early detection if allowed to do (McCarthy et al, 2017). However, if the lack of knowledge and awareness greatly influences a person in making decisions, other studies reveal that only a few women have undergone Pap smears, according to the facts the plethora of women $(80,9 \%)$ are not awareness of cervical cancer and are conscious screening. very low. Low screening rates underscore the fact that women weren't told about how important the benefits of 
Pap smear testing in cervical cancer prevention and screening (Belglaiaa et al, 2018). Hossana women where $(85,8 \%)$ had been not yet implemented to different excuses, women still searched for health information 209 (35.8\%), did not seek health information because they never heard of cervical cancer. Followed by never having had the disease before 111 (19\%) (Habtu et al, 2018). The decision to be screened is very motivating, as motivated women are 3,704 times more be screening for cervical cancer. Therefore, motivation of maternal is ideally target for cervical cancer prevention counseling (Sidabutar et al., 2017).

\section{Barriers}

The majority of women are considered shy and education is the reason for ignorance of cervical cancer (Khan et al, 2014). Lack of knowledge and awareness makes a person tend to withdraw from the surrounding environment. Lack of knowledge about cervical cancer, as well as inadequate information makes a woman embarrassed and anxious for the embarrassment of the examination. The findings suggest that women who are submissive and shy may delay looking for help with them problems, it has been shown that factors of psychosocial are particularly influential on women because stress, pessimism, and quality of shame may has played some role in both cervical cancer and HPV-mediated screening in HIVpositive patients. Some women expressed anxiety and worry about the diagnosis from the examination results (Tiwari et al, 2011)

However,in Pakistan is taboo to discuss about sexually transmitted disease and sex's education, more woman, especially rural women, have a low understanding of sexual communicable disease and cervical cancer. Possible because, HPV is caused of cervical cancer ranks as third leading cause of death in Pakistan women (Javaeed et al., 2019). In another study, late detection of health was strongly associated with a lack of awareness of cervical cancer, the performance of religious ceremonies to treat the disease, and the anticipation of additional symptoms before going to a medical facility. Similarly, the delay in delivery of diagnostic products is closely related to the first contact with primary medical institutions and visits to various medical institutions for preliminary diagnosis (Dereje et al., 2020).

\section{CONCLUSION}

Factors that influence a woman done early detection of cervical cancer include knowledge and education where good knowledge can create awareness for a woman to do screening, apart from that importance of information sources in the form of health promotion and socialization can encourage women to perform early detection. Decision making a best conclusion after women get a variety of information. Decision-making is very important in determining goals through the implementation of actions to be taken next. Despite the low awareness of HPV, mostly female are realized of cervical cancer as a deadly ailment, after knowing the various effects of the dangers of cervical cancer, women should be able to decide perform early detection of cervical cancer or not and Limited knowledge and awareness are obstacles that make a person tend to withdraw from the surrounding environment. Lack of knowledge about cervical cancer, as well as inadequate information makes a woman embarrassed and anxious about the embarrassment of 
the examination and women feel worried, nervous about the results of the examination.

\section{REFERENCES}

Al-Amro, S. Q., Gharaibeh, M. K., \& Oweis, A. I. (2020). Factors associated with cervical cancer screening uptake: Implications for the health of women in Jordan. Infectious Diseases in Obstetrics and Gynecology, 2020. https://doi.org/10.1155/2020/9690473

Andrijono. (2017). Cervical Cancer Management Guide, Cervical Cancer Management Committee. http://kanker.kemkes.go.id/guidelines/PPKServiks.pdf

Arksey, H., \& O'Malley, L. (2005). Scoping studies: towards a methodological framework. International Journal of Social Research Methodology, 8(1), 19-32. https://doi.org/10.1080/1364557032000119616

Belglaiaa, E., Souho, T., Badaoui, L., Segondy, M., Prétet, J. L., Guenat, D., \& Mougin, C. (2018). Awareness of cervical cancer among women attending an HIV treatment centre: A crosssectional study from Morocco. BMJ Open, 8(8), 1-8. https://doi.org/10.1136/bmjopen2017-020343

Bettany. (2012). How to do a Systematic Literature Review in Nursing.

Bhatt, J., \& Bathija, P. (2018). Ensuring access to quality health care in vulnerable communities. Academic Medicine, 93(9), 1271-1275. https://doi.org/10.1097/ACM.0000000000002254

Binka, C., Doku, D. T., \& Awusabo-Asare, K. (2017). Experiences of cervical cancer patients in rural Ghana: An exploratory study. PLoS ONE, 12(10), 1-12. https://doi.org/10.1371/journal.pone.0185829

Butsashvili, M., Abzianidze, T., Kajaia, M., Agladze, D., Kldiashvili, E., Bednarczyk, R., McNutt, L. A., \& Kamkamidze, G. (2015). Seroprevalence and awareness of human papillomavirus infection and cervical cancer screening results among reproductive-aged Georgian women. Journal of Family Planning and Reproductive Health Care, 41(4), 265271. https://doi.org/10.1136/jfprhc-2013-100833

Can, H., Erdem, O., Oztekin, C., Celik, S. B., Onde, M., Celepkolu, T., \& Ongel, K. (2014). Are primary health care workers aware of cervical cancer risk? Asian Pacific Journal of Cancer Prevention, 15(16), 6669-6671. https://doi.org/10.7314/APJCP.2014.15.16.6669

Cunningham, M. S., Skrastins, E., Fitzpatrick, R., Jindal, P., Oneko, O., Yeates, K., Booth, C. M., Carpenter, J., \& Aronson, K. J. (2015). Cervical cancer screening and HPV vaccine acceptability among rural and urban women in Kilimanjaro Region, Tanzania. BMJ Open, 5(3), 1-10. https://doi.org/10.1136/bmjopen-2014-005828

Dereje, N., Addissie, A., Worku, A., Assefa, M., Abraha, A., Tigeneh, W., Kantelhardt, E. J., \& Jemal, A. (2020). Extent and predictors of delays in diagnosis of cervical cancer in Addis Ababa, Ethiopia: A population-based prospective study. Journal of Global Oncology, 6, 277-284. https://doi.org/10.1200/JGO.19.00242

Endalew, D. A., Moti, D., Mohammed, N., Redi, S., \& Alemu, B. W. (2020). Knowledge and practice of cervical cancer screening and associated factors among reproductive age group women in districts of Gurage zone, Southern Ethiopia. A cross-sectional study. PLoS ONE, 15(9 September), 1-13. https://doi.org/10.1371/journal.pone.0238869

Fentie, A. M., Tadesse, T. B., \& Gebretekle, G. B. (2020). Factors affecting cervical cancer 
screening uptake, visual inspection with acetic acid positivity and its predictors among women attending cervical cancer screening service in Addis Ababa, Ethiopia. BMC Women's Health, 20(1), 1-10. https://doi.org/10.1186/s12905-020-01008-3

Gemeda, E. Y., Kare, B. B., Negera, D. G., Bona, L. G., Derese, B. D., Akale, N. B., Kebede, K. M., Koboto, D. D., \& Tekle, A. G. (2020). Prevalence and Predictor of Cervical Cancer Screening Service Uptake Among Women Aged 25 Years and Above in Sidama Zone, Southern Ethiopia, Using Health Belief Model. Cancer Control, 27(1), 1-8. https://doi.org/10.1177/1073274820954460

Habtu, Y., Yohannes, S., \& Laelago, T. (2018). Health seeking behavior and its determinants for cervical cancer among women of childbearing age in Hossana Town, Hadiya zone, Southern Ethiopia: Community based cross sectional study. BMC Cancer, 18(1), 1-9. https://doi.org/10.1186/s12885-018-4203-2

Heena, H., Durrani, S., Alfayyad, I., Riaz, M., Tabasim, R., Parvez, G., \& Abu-Shaheen, A. (2019). Knowledge, Attitudes, and Practices towards Cervical Cancer and Screening amongst Female Healthcare Professionals: A Cross-Sectional Study. Journal of Oncology, 2019. https://doi.org/10.1155/2019/5423130

Javaeed, A., Shoukat, S., Hina, S., Hameed, Z., Ghauri, S. K., \& Ahmed, M. M. (2019). Knowledge, Attitude, and Practices Related to Cervical Cancer Among Adult Women in Azad Kashmir: A Hospital-based Cross-sectional Study. Cureus, 11(3). https://doi.org/10.7759/cureus.4234

Kasa, A. S., Tesfaye, T. D., \& Temesgen, W. A. (2018). Knowledge, attitude and practice towards cervical cancer among women in Finote Selam city administration, West Gojjam Zone, Amhara Region, North West Ethiopia, 2017. African Health Sciences, 18(3), 623-636. https://doi.org/10.4314/ahs.v18i3.20

Khan, G. J., Naeem, H. S., Khan, S., Jamshaid, T., Sajid, M. I., Bashir, I., \& Jamshaid, M. (2014). Understanding and responsiveness level about cervical cancer and its avoidance among young women of Pakistan. Asian Pacific Journal of Cancer Prevention, 15(12), 4877-4883. https://doi.org/10.7314/APJCP.2014.15.12.4877

Levac, D., Colquhoun, H., \& O’Brien, K. K. (2010). Scoping studies: advancing the methodology. Implementation Science, 5(1), 69. https://doi.org/10.1186/1748-5908-5-69

McCarthy, S. H., Walmer, K. A., Boggan, J. C., Gichane, M. W., Calo, W. A., Beauvais, H. A., \& Brewer, N. T. (2017). Awareness of Cervical Cancer Causes and Predeterminants of Likelihood to Screen among Women in Haiti. Journal of Lower Genital Tract Disease, 21(1), 37-41. https://doi.org/10.1097/LGT.0000000000000281

O’Connor, M., Costello, L., Murphy, J., Prendiville, W., Martin, C. M., O'Leary, J. J., \& Sharp, L. (2015). Influences on human papillomavirus (HPV)-related information needs among women having HPV tests for follow-up of abnormal cervical cytology. Journal of Family Planning and Reproductive Health Care, 41(2), 134-141. https://doi.org/10.1136/jfprhc2013-100750

Obalase, S. B., Akindutire, I. O., Adelusi, J. O., \& Adegboro, J. S. (2017). Knowledge and Awareness of Cervical Cancer Screening Among Women of Reproductive Age in Ikere Ekiti Local Government Area, Ekiti State, Nigeria. International Journal of Caring Sciences, $\quad$ 10(2), 755-763. http://search.ebscohost.com/login.aspx?direct=true $\& d b=r z h \& A N=124801494 \&$ site=ehostlive

Riza, E., Karakosta, A., Tsiampalis, T., Lazarou, D., Karachaliou, A., Ntelis, S., Karageorgiou, 
V., \& Psaltopoulou, T. (2020). Knowledge, attitudes and perceptions about cervical cancer risk, prevention and human papilloma virus (HPV) in vulnerable women in Greece. International Journal of Environmental Research and Public Health, 17(18), 1-20. https://doi.org/10.3390/ijerph17186892

Shiferaw, N., Brooks, M. I., Salvador-Davila, G., Lonsako, S., Kassahun, K., Ansel, J., Osakwe, C., Weldegebreal, T., Ahmed, I., Asnake, M., \& Blumenthal, P. D. (2016). Knowledge and Awareness of Cervical Cancer among HIV-Infected Women in Ethiopia. Obstetrics and Gynecology International, 2016. https://doi.org/10.1155/2016/1274734

Sidabutar, S., Martini, S., \& Wahyuni, C. U. (2017). Analysis of factors affecting women of childbearing age to screen using visual inspection with acetic acid. Osong Public Health and Research Perspectives, 8(1), 61-64. https://doi.org/10.24171/j.phrp.2017.8.1.08

Tiwari, A., Kishore, J., \& Tiwari, A. (2011). Perceptions and concerns of women undergoing Pap smear examination in a tertiary care hospital of India. Indian Journal of Cancer, 48(4), 477482. https://doi.org/10.4103/0019-509X.92261

Touch, S., \& Oh, J. K. (2018). Knowledge, attitudes, and practices toward cervical cancer prevention among women in Kampong Speu Province, Cambodia. BMC Cancer, 18(1), 18. https://doi.org/10.1186/s12885-018-4198-8

UNFPA. (2015). Cervical Cancer Prevention Campaign Kicks Off in the Western Balkans. http://www.unfpa.org/news/cervical-cancer-prevention-campaign-kicks-western-balkans

WHO. (2016). UN Joint Global Programme on Cervical Cancer Prevention and Control. 1-4. http://www.who.int/ncds/un-task-force/un-joint-action-cervical-cancer-leaflet.pdf

WHO. (2018). Internasional Agency for Research on Cancer. September, 13-15. http://gco.iarc.fr/,

Yuanyue, L., Baloch, Z., Shanshan, L., Yasmeen, N., Xiaomei, W., Khan, J. M., \& Xueshan, X. (2018). Cervical Cancer, Human Papillomavirus Infection, and Vaccine-Related Knowledge: Awareness in Chinese Women. Cancer Control, 25(1), 1-8. https://doi.org/10.1177/1073274818799306 